\title{
Ochrona zabytków nieruchomych i ich nazw
}

\section{The legal protection of immovable monuments and their names}

\section{Streszczenie}

W artykule przedstawiono potrzebę przyjęcia w Polsce efektywnej i sprawnej regulacji prawnej dotyczącej ochrony nazw, które nie powinny być zmieniane ze względu na swoje znaczenie kulturowe bądź historyczne. Zaprezentowano również metodę prawnej ochrony zabytków nieruchomych w Polsce, w tym obowiązki właściciela, formy ochrony, kontrolę i nadzór nad właścicielem, problematykę finansowania oraz organy ochrony zabytków.

Słowa kluczowe: prawo ochrony zabytków, ochrona nazw zabytków, zabytki nieruchome

Abstract

This paper discusses the need for adopting effective and efficient legal regulation in Poland regarding the protection of names which should not be changed due to their cultural or historical significance. Also discussed are the methods of legal protection of immovable monuments in Poland, including the responsibilities of the owner, forms of protection, supervision and control over the owner, the issue of financing and authorities of monuments protection.

Keywords: monument protection law, immovable monuments, protection of monument names 


\section{WPROWADZENIE}

Problematyka prawnej ochrony nazw, które nie powinny być zmieniane ze względu na swoje znaczenie kulturowe bądź historyczne, nie należy do często poruszanych tematów opracowań z dziedziny prawnej ochrony zabytków. Wśród prac traktujących o niej należy wskazać artykuł Piotra Dobosza Ochrona nazw historycznych w obrębie prawnej ochrony zabytków ${ }^{1}$. Nazwy o szczególnym znaczeniu historycznym bądź kulturowym należą do kategorii dóbr niematerialnych chronionych przez prawo administracyjne.

\section{POJĘCIE DÓBR O CHARAKTERZE NIEMATERIALNYM}

Cechami dóbr o charakterze niematerialnym są odrębność w stosunku do innych dóbr oraz istota niezwiązana z przedmiotami namacalnymi². Zasadniczo dobra te dzielą się na dobra osobiste oraz dobra koncepcyjne. Dobra osobiste są ściśle związane z człowiekiem i jego prywatnymi interesami. Zalicza się do nich między innymi dobra wskazane w art. 23 k.c. ${ }^{3}$, takie jak np. wolność, cześć, nazwisko, pseudonim. Dobrami koncepcyjnymi są wytwory ludzkiego umysłu mające wyodrębniony charakter. Zaliczamy do nich między innymi utwory, np. artystyczne, architektoniczne, programy komputerowe oraz wynalazki. Nie jest to podział wyczerpujący. Istnieje wiele rodzajów dóbr niematerialnych niemieszczących się w żadnej z tych kategorii. Wśród nich znajdują się dobra niematerialne chronione przez prawo administracyjne. Mają one charakter publiczny, co oznacza, że ich ochrona jest zasadna z uwagi na interes publiczny. Są to np. język polski, dobra o charakterze ogólnonarodowym (godło, barwa, hymn Rzeczpospolitej Polskiej), a także niektóre dobra będące przedmiotem ochrony konserwatorskiej.

\section{ISTOTA NAZWY Z PERSPEKTYWY PRAWNICZEJ}

W polskim systemie prawnym nie odnajdziemy legalnej definicji nazwy. W związku z tym powinniśmy odwołać się do jej słownikowej definicji. Według Słownika języka polskiego oznacza ona wyraz albo połączenie wyrazowe oznaczające kogoś lub cośt. Niewątpliwie nazwa należy do kategorii dóbr niematerialnych. Może podlegać ochronie prawa prywatnego lub prawa publicznego. Cywilnoprawnej ochronie podlega np. nazwa przedsiębiorstwa. Według art. 43 k.c. przepisy o ochronie dóbr osobistych osób fizycznych stosuje się odpowiednio do osób prawnych. Dobrem osobistym przedsiębiorstwa (osoby prawnej) jest z pewnością jego nazwa. Prawo administracyjne chroni dobra istotne ze względu na interes ogółu społeczeństwa. Wśród nich należy wyróżnić także nazwy urzędowe oraz historyczne lub tradycyjne nazwy budynku, placu, ulicy czy jednostki osadniczej. 


\section{CHARAKTERYSTYKA USTAWOWEJ OCHRONY ZABYTKÓW I OPIEKI NAD ZABYTKAMI Z PERSPEKTYWY DÓBR RUCHOMYCH, NIERUCHOMYCH, NIEMATERIALNYCH}

Obowiązująca w Polsce regulacja ustawowa skupia się na ochronie rzeczy ruchomych oraz nieruchomych. Nie pomija jednak całkowicie dóbr niematerialnych.

\subsection{OCHRONA ZABYTKÓW NIERUCHOMYCH W USTAWIE O OCHRONIE ZABYTKÓW I OPIECE NAD ZABYTKAMI ${ }^{5}$}

Ochroną zabytków nieruchomych objęte są zabytki wpisane do rejestru zabytków, obiekty uznane za pomniki historii, parki kulturowe oraz strefa ochrony konserwatorskiej w miejscowym planie zagospodarowania przestrzennego. Poniższe informacje skupiają się wokół ochrony zabytków wpisanych do rejestru.

\subsubsection{FORMY OCHRONY}

Jako podstawową formę ochrony zabytku nieruchomego należy wskazać wpis do rejestru zabytków, prowadzonego przez wojewódzkiego konserwatora zabytków. Na podstawie jego decyzji wpisuje się zabytek nieruchomy do rejestru. Decyzja ta wydawana jest na wniosek lub z urzędu. Wpis zabytku nieruchomego do rejestru ujawnia się w księdze wieczystej prowadzonej do danej nieruchomości na wniosek wojewódzkiego konserwatora zabytków na podstawie decyzji o wpisie do rejestru zabytków. Z rejestru skreślenia dokonuje się na podstawie decyzji ministra właściwego do spraw kultury i ochrony dziedzictwa narodowego w przypadku, gdy zabytek uległ zniszczeniu w stopniu powodującym utratę jego wartości historycznej, artystycznej lub naukowej albo którego wartość będąca podstawą wydania decyzji o wpisie do rejestru nie została potwierdzona w nowych ustaleniach naukowych. Istotna teza została wyrażona przez Wojewódzki Sąd Administracyjny w Warszawie w wyroku z dnia 9 października 2013 r. - nawet obiekt będący ruiną, jeżeli zachowuje jedną z podlegających ochronie wartości, nie może zostać wykreślony z rejestru zabytków ${ }^{6}$.

\subsubsection{OBOWIĄZKI WŁAŚCICIELA LUB POSIADACZA ZABYTKU}

Właściciel lub posiadacz zabytku nieruchomego obowiązany jest posiadanie dokumentacji konserwatorskiej określającej stan zachowania zabytku nieruchomego i możliwości jego adaptacji, z uwzględnieniem jego funkcji historycznej i wartości, a także dokumentów uzgodnionych z wojewódzkim konserwatorem zabytków programu prac konserwatorskich oraz programu zagospodarowania zabytku nieruchomego wraz z otoczeniem oraz dalszego 
korzystania z tego zabytku, z uwzględnieniem wyeksponowania jego wartości. Program prac konserwatorskich musi określać zakres i sposób ich prowadzenia oraz wskazywać niezbędne do zastosowania materiały i technologie. Ponadto właściciel lub posiadacz zabytku nieruchomego musi zawiadamiać wojewódzkiego konserwatora zabytków o uszkodzeniu lub zniszczeniu zabytku, zagrożeniu dla niego, a także zmianie dotyczącej jego stanu prawnego. Karze grzywny podlegać będzie ten, kto będąc właścicielem lub posiadaczem zabytku wpisanego do rejestru lub innego zabytku znajdującego się w wojewódzkiej ewidencji zabytków, nie powiadomił odpowiednio ministra właściwego do spraw kultury i ochrony dziedzictwa narodowego albo wojewódzkiego konserwatora zabytków o: uszkodzeniu, zniszczeniu, zaginięciu lub kradzieży zabytku niezwłocznie po powzięciu wiadomości o wystąpieniu zdarzenia, zagrożeniu dla zabytku niezwłocznie po powzięciu wiadomości o wystąpieniu zagrożenia, zmianie miejsca przechowania zabytku ruchomego w terminie miesiąca od dnia nastąpienia tej zmiany, zmianach dotyczących stanu prawnego zabytku nie później niż w terminie miesiąca od dnia ich wystąpienia lub powzięcia o nich wiadomości. W tym przypadku można także orzec nawiązkę do wysokości dwudziestokrotnego minimalnego wynagrodzenia na wskazany cel społeczny związany z opieką nad zabytkami. Dodatkowo właściciel lub posiadacz ma obowiązek udostępnić zabytek w celu przeprowadzenia badań. Każdy, kto uniemożliwia lub utrudnia dostęp do zabytku organowi ochrony zabytków, wykonującemu uprawnienia wynikające z ustawy, podlega karze grzywny oraz administracyjnej karze pieniężnej w wysokości od 500 do 2000 zł.

\subsubsection{NADZÓR I KONTROLA}

Skutkiem wpisu do rejestru jest objęcie zabytku prawną ochroną. Przejawia się ona m.in. nadzorem konserwatorskim. Kontrolę przestrzegania i stosowania przepisów prowadzą wojewódzki konserwator zabytków lub upoważnieni przez niego pracownicy urzędu. Podczas kontroli upoważnieni są oni do wstępu na teren nieruchomości w przypadku, gdy istnieje uzasadnione podejrzenie zniszczenia lub uszkodzenia zabytku, oceny stanu zachowania, warunków zabezpieczenia zabytków, sprawdzania zgodności wszelkich działań podejmowanych przy zabytkach wpisanych do rejestru oraz prowadzonych badań archeologicznych z zakresem lub warunkami określonymi w pozwoleniu i zatwierdzoną dokumentacją, żądania ustnych lub pisemnych informacji w zakresie niezbędnym dla ustalenia stanu faktycznego dotyczącego zakresu kontroli, żądania okazania dokumentów i udostępniania wszelkich danych mających związek z zakresem kontroli oraz dokonania wpisu w dzienniku budowy w zakresie określonym przepisami prawa budowlanego. Czynności kontrolne wykonuje się w obecności kontrolowanej osoby fizycznej albo kierownika kontrolowanej jednostki organizacyjnej. Z czynności kontrolnych sporządza się protokół. Zawiera on opis stanu faktycznego, w tym ustalonych nieprawidłowości z uwzględnieniem przyczyn powstania, zakresu i skutków tych nieprawidłowości oraz osób za nie odpowiedzialnych. Zostaje on podpisany przez 
kontrolującego i kontrolowanego, który może wnieść do protokołu umotywowane zastrzeżenia i uwagi. Jeden egzemplarz protokołu dostarcza się kontrolowanemu. Mogą zostać wydane zalecenia pokontrolne usunięcia stwierdzonych nieprawidłowości, na które w terminie 14 dni od dnia otrzymania zaleceń kontrolowany można zgłosić pisemnie umotywowane zastrzeżenia do zaleceń pokontrolnych oraz dodatkowe wyjaśnienia lub przedstawić dodatkową dokumentację. Kto nie wykonuje zaleceń pokontrolnych, podlega karze grzywny oraz administracyjnej karze pieniężnej w wysokości od 500 do 50000 zł.

\subsubsection{FINANSOWANIE}

Osoba fizyczna lub jednostka organizacyjna posiadająca tytuł prawny do zabytku, wynikający z prawa własności, użytkowania wieczystego, trwałego zarządu, ograniczonego prawa rzeczowego albo stosunku zobowiązaniowego finansuje prowadzenie prac konserwatorskich, restauratorskich i robót budowlanych przy tym zabytku. Może ona ubiegać się o udzielenie dotacji celowej z budżetu państwa na dofinansowanie prac konserwatorskich, restauratorskich lub robót budowlanych przy zabytku wpisanym do rejestru. Dotacja ta udzielana jest przez ministra właściwego do spraw kultury i ochrony dziedzictwa narodowego lub wojewódzkiego konserwatora zabytków na dofinansowanie nakładów koniecznych na wykonanie prac konserwatorskich, restauratorskich lub robót budowlanych przy zabytku. Może ona pokrywać wydatki na prace, które mają zostać przeprowadzone w roku złożenia przez wnioskodawcę wniosku o udzielenie dotacji lub w roku następującym po roku złożenia tego wniosku, albo prace, które zostały przeprowadzone w okresie trzech lat poprzedzających rok złożenia przez wnioskodawcę wniosku o udzielenie dotacji. W pierwszym przypadku odbywa się to według zasad ustalonych na podstawie kosztorysu zatwierdzonego przez wojewódzkiego konserwatora zabytków. Dotacja może być udzielona w wysokości do $50 \%$ nakładów koniecznych na wykonanie prac konserwatorskich, restauratorskich lub robót budowlanych. Może być ona udzielona w wysokości do 100\% nakładów koniecznych na wykonanie tych prac lub robót, jeżeli stan zachowania zabytku wymaga niezwłocznego podjęcia prac lub ze względu na wyjątkową wartość historyczną, artystyczną lub naukową zabytku, albo gdy wymaga on przeprowadzenia złożonych pod względem technologicznym prac konserwatorskich, restauratorskich lub robót budowlanych. Prace konserwatorskie, restauratorskie i roboty budowlane przy zabytkach będących w posiadaniu jednostek organizacyjnych, zaliczanych do sektora finansów publicznych, są finansowane ze środków finansowych przyznanych odpowiednio przez dysponentów części budżetowych bądź jednostki samorządu terytorialnego, którym podlegają te jednostki. Na powyższe dofinansowanie przeznaczone są środki Narodowego Funduszu Ochrony Zabytków. Jego dysponentem jest minister właściwy do spraw kultury i ochrony dziedzictwa narodowego, a przychodem są wpływy z administracyjnych kar pieniężnych określonych w ustawie. 


\subsubsection{ORGANY OCHRONY ZABYTKÓW}

Organami ochrony zabytków są: minister właściwy do spraw kultury i ochrony dziedzictwa narodowego, w imieniu którego zadania i kompetencje w tym zakresie wykonuje Generalny Konserwator Zabytków oraz wojewoda, w imieniu którego zadania i kompetencje w tym zakresie wykonuje wojewódzki konserwator zabytków. Generalny Konserwator Zabytków jest sekretarzem lub podsekretarzem stanu w urzędzie obsługującym ministra właściwego do spraw kultury i ochrony dziedzictwa narodowego. Wojewódzkiego konserwatora zabytków powołuje i odwołuje wojewoda na wniosek Generalnego Konserwatora Zabytków (albo odwołuje za zgodą), natomiast zastępcę wojewódzkiego konserwatora zabytków powołuje i odwołuje wojewoda na wniosek wojewódzkiego konserwatora zabytków. Wojewódzki konserwator zabytków jest organem wojewódzkiej administracji zespolonej. Kieruje on wojewódzkim urzędem ochrony zabytków. Przy ministrze właściwym do spraw kultury i ochrony dziedzictwa narodowego działa Rada Ochrony Zabytków. Jej członków w liczbie od 10 do 20 powołuje na okres 5 lat i odwołuje minister właściwy do spraw kultury i ochrony dziedzictwa narodowego. Przy Generalnym Konserwatorze Zabytków działa Główna Komisja Konserwatorska jako organ opiniodawczy do spraw działań konserwatorskich podejmowanych przy zabytkach. Jej członków w liczbie od 10 do 15 powołuje na okres 5 lat i odwołuje Generalny Konserwator Zabytków. Przy wojewódzkim konserwatorze zabytków działa Wojewódzka Rada Ochrony Zabytków jako organ opiniodawczy w zakresie ochrony zabytków i opieki nad zabytkami. W jej skład wchodzi od 5 do 10 członków, powoływanych na okres 5 lat i odwoływanych przez wojewódzkiego konserwatora zabytków po uzyskaniu pozytywnej opinii Generalnego Konserwatora Zabytków. Ponadto istnieją rzeczoznawcy, którym uprawnienia nadaje minister właściwy do spraw kultury i ochrony dziedzictwa narodowego.

\subsubsection{OCENA ROZWIAZZAŃ}

Art. 5 Konstytucji RP7 mówi, że Rzeczpospolita Polska strzeże dziedzictwa narodowego, kierując się zasadą zrównoważonego rozwoju. Zasada ta wyjaśnia, że zrównoważony rozwój powinien polegać na takim prowadzeniu wszelkich procesów rozwojowych, żeby zachować równowagę m.in. pomiędzy podejmowanymi inwestycjami a ograniczeniami, jakie mogą spowodować ${ }^{8}$. Zachowanie zabytku w jak najlepszym stanie niewątpliwie leży w interesie publicznym. Ustawa jednak nakłada na dysponenta zabytku wiele obowiązków, niejako przerzucając na niego odpowiedzialność. Wypełnianie tych obowiązków wymaga często wysokich nakładów pieniężnych, nierzadko niemożliwych do zrealizowania. Skutkiem tego jest bierność dysponenta zabytku oraz organów administracji publicznej. To z kolei powoduje niszczenie zabytku, co stanowi brak realizacji normy z art. 5 Konstytucji RP. 


\subsection{OCHRONA DÓBR NIEMATERIALNYCH W USTAWIE O OCHRONIE ZABYTKÓW I OPIECE NAD ZABYTKAMI}

Za dobro niematerialne należy uznać krajobraz kulturowy. W celu jego ochrony rada gminy może, na podstawie uchwały, po zasięgnięciu opinii wojewódzkiego konserwatora zabytków utworzyć park kulturowy. Uchwała ta określa nazwę parku kulturowego, jego granice, sposób ochrony, a także określone zakazy i ograniczenia. Wójt, burmistrz, prezydent miasta sporządza plan ochrony parku kulturowego w uzgodnieniu z wojewódzkim konserwatorem zabytków. Plan ten podlega zatwierdzeniu przez radę gminy. Rada gminy może utworzyć jednostkę organizacyjną do zarządzania parkiem. Dla obszaru, na którym został utworzony park kulturowy, obowiązkowo musi zostać sporządzony miejscowy plan zagospodarowania przestrzennego.

\subsubsection{OCHRONA NAZW W USTAWIE O OCHRONIE ZABYTKÓW I OPIECE NAD ZABYTKAMI}

Zgodnie z art. 6 ust. 2 u.o.z.o.z. ochronie mogą podlegać nazwy geograficzne, historyczne lub tradycyjne nazwy obiektu budowlanego, placu, ulicy lub jednostki osadniczej. Ochrona, o której mowa w tym przepisie, pojawia się w ustawie jedynie w dwóch przypadkach. Podczas wpisu zabytku nieruchomego do rejestru na podstawie decyzji wydanej przez wojewódzkiego konserwatora zabytków może być wpisana nazwa geograficzna, historyczna lub tradycyjna tego zabytku. Wpis ten ma charakter fakultatywny i akcesoryjny, a co za tym idzie, nie jest możliwy sam wpis nazwy geograficznej, historycznej lub tradycyjnej bez wpisu zabytku. Ponadto brak w ustawie określenia skutków tego wpisu. Nie przewiduje się środków nadzoru konserwatorskiego ani form oddziaływania prewencyjnego ze strony organów ochrony zabytków w sytuacji zagrożenia dla zachowania określonej nazwy ${ }^{9}$. Drugim przypadkiem jest artykuł 16 ust. 2 ustawy, mówiący, że uchwała rady gminy tworząca park kulturowy musi określać jego nazwę. Mamy tutaj do czynienia z niemal analogiczną sytuacją. Różnica polega jednak na obligatoryjnym charakterze określenia nazwy w uchwale. Jak widzimy, brakuje w ustawie konkretnych norm odnoszących się do ochrony nazw zabytków. W szczególności brakuje przepisów mających na celu zagwarantowanie stałości nazw geograficznych, historycznych lub tradycyjnych nazw obiektu budowlanego, placu, ulicy lub jednostki osadniczej. W związku z tym nazwy, które niewątpliwie odnoszą się do dziedzictwa kulturowego, pozbawione są praktycznej ochrony.

\subsubsection{PRZYKŁADY NAZW OBIEKTÓW}

Na przestrzeni lat prawo nie zdołało zapewnić należytej ochrony historycznym lub tradycyjnym nazwom. Zmiany następowały głównie dla podkreślenia zasług określonych osób. Przykładowo można wskazać ul. Bolesława Limanowskiego w Krakowie. Jest to jedna 
z najstarszych ulic Podgórza, pierwotnie nazywana ul. Lwowską, ze względu na fakt, iż prowadziła w stronę tego miasta. W roku 1935 zmieniono jej nazwę na cześć znanego polityka. Podobnie ul. Marszałka Józefa Piłsudskiego, łącząca Stare Miasto z Błoniami, pierwotnie nosiła nazwę ul. Wolska. Nazwa ta podkreślała kierunek Woli Justowskiej, która nazwę swą czerpie od imienia swego właściciela od roku 1528 - Justusa Decjusza, sekretarza i rajcy królewskiego. Powyższe nazwy mają znaczenie historyczne.

\section{WNIOSKI KOŃCOWE}

Obecnie zmiana nazwy zabytku jest teoretycznie możliwa. Dzieje wielu miast opisane są przez nazwy ich ulic, parków, osiedli czy budynków. W przypadku ich modyfikacji historia ta z czasem uległaby zniekształceniu. Nazewnictwo miejscowe, które jest szczególnym zapisem dziejów miasta, powinno podlegać ochronie takiej, jak zabytki materialne ${ }^{10}$. Wobec tego należy zastanowić się nad potrzebą stworzenia efektywnej regulacji prawnej, dotyczącej ochrony nazw o znaczeniu kulturowym lub historycznym. W związku z powyższym wydaje się potrzebne utworzenie legalnej definicji nazwy zabytku, która mogłaby zostać umieszczona w art. 3 u.o.z.o.z. Określiłaby ona granice interpretacji terminów zawartych w art. 6 ust. 2 u.o.z.o.z., tj. nazwy geograficznej, historycznej lub tradycyjnej nazwy obiektu budowlanego, placu, ulicy lub jednostki osadniczej. Dzięki temu norma ta zyskałaby konkretniejszy wymiar, a co za tym idzie, zostałyby stworzone jasne przesłanki, jakie nazwa musi spełniać, aby zasługiwać na prawną ochronę. Wydaje się także dobrym rozwiązaniem utworzenie odrębnego rejestru dla nazw, które powinny być chronione ze względu na tradycyjne lub historyczne znaczenie. Do rejestru wpis następowałby na podstawie decyzji jednego z organów ochrony zabytków. Wpis ten ograniczałby w określony sposób swobodę organów samorządu terytorialnego w modyfikowaniu tych nazw. W konsekwencji zmiana takiej nazwy byłaby wyłączona z typowego trybu zmian, co zapewniłoby jej względną stałość. Takie rozwiązania zabezpieczałyby nazwy przed kolejnymi zmianami. Dzięki temu zostałaby im zapewniona ochrona, której obecnie są faktycznie pozbawione.

\section{PRZYPISY}

1 P. Dobosz, Ochrona nazw historycznych w obrębie prawnej ochrony zabytków, „Ochrona Zabytków" 39, 1(152)/1985, s. 23-29.

2 R. Golat, Dobra niematerialne. Kompendium prawne, Oficyna Wydawnicza Branta, Bydgoszcz-Warszawa 2006.

3 Ustawa z dnia 23 kwietnia 1964 r. - kodeks cywilny, Dz. U. z 2019 r. poz. 1145, dalej k.c. 
4 Słownik języka polskiego, red. M. Szymczak, t. 2, Państwowe Wydawnictwo Naukowe, Warszawa 1979.

5 Ustawa z dnia 23 lipca 2003 r. o ochronie zabytków i opiece nad zabytkami, Dz.U. z 2018 r. poz. 2067.

6 Wyrok Wojewódzkiego Sądu Administracyjnego w Warszawie z dnia 9 października 2013 r., sygn. VII SA/Wa 1179/13, Lex nr 1644449.

7 Konstytucja Rzeczypospolitej Polskiej z dnia 2 kwietnia 1997 r., Dz.U. 1997 nr 78 poz. 483 z późn. zm.

8 J. Zimmermann, Prawo administracyjne, wyd. 7, Warszawa 2006, s. 168.

9 Wykład prawa ochrony zabytków, red. K. Zalasińska, K. Zeidler, Wydawnictwo Uniwersytetu Gdańskiego, Warszawa-Gdańsk 2015, s. 81.

10 K. Handke, Nazewnictwo miejskie - świadek epoki i cenny zabytek, "Ochrona Zabytków” 3-4/2004, s. 125.

\section{BIBLIOGRAFIA}

Dobosz P., Ochrona nazw historycznych w obrębie prawnej ochrony zabytków, „Ochrona Zabytków" 39, 1(152)/1986, 23-29.

Golat R., Dobra niematerialne. Kompendium prawne, Oficyna Wydawnicza Branta, BydgoszczWarszawa 2006.

Handke K., Nazewnictwo miejskie - świadek epoki i cenny zabytek, „Ochrona Zabytków” 3-4/2004, 115-126.

Słownik języka polskiego, red. M. Szymczak, t. 2, Państwowe Wydawnictwo Naukowe, Warszawa 1979.

Wykład prawa ochrony zabytków, red. K. Zalasińska, K. Zeidler, Wydawnictwo Uniwersytetu Gdańskiego, Warszawa-Gdańsk 2015.

Zimmermann J., Prawo administracyjne, wyd. 7, Wolters Kluwer, Warszawa 2006.

Akty normatywne

Konstytucja Rzeczypospolitej Polskiej z dnia 2 kwietnia 1997 r., Dz.U. 1997 nr 78 poz. 483 z późn. zm.

Ustawa z dnia 23 kwietnia 1964 r. - kodeks cywilny, Dz. U. z 2019 r. poz. 1145.

Ustawa z dnia 23 lipca 2003 r. o ochronie zabytków i opiece nad zabytkami, Dz.U. z 2018 r. poz. 2067.

Orzecznictwo

Wyrok Wojewódzkiego Sądu Administracyjnego w Warszawie z dnia 9 października 2013 r., sygn. VII SA/Wa 1179/13, Lex nr 1644449.

ADRES BIBLIOGRAFICZNY ARTYKU UU: Pawlus F., Ochrona zabytków nieruchomych i ich nazw, Przestrzeń/Urbanistyka/Architektura, 2/2019, s. 51-60. 